\title{
PENERAPAN METODE KARYAWISATA DALAM \\ PEMBELAJARAN MENULIS KARYA SASTRA (CERPEN)
}

\section{DIAN LUFIA RAHMAWATI}

\section{Tenaga Pengajar pada Program Studi PGSD FKIP Universitas Muhammadiyah Palangkaraya}

\begin{abstract}
ABSTRAK
Pembelajaran sastra di sekolah seharusnya diarahkan pada penumbuhan apresiasi sastra para siswa sesuai dengan tingkat kematangan emosionalnya. Pengembangan pembelajaran sastra secara kreatif dan inovatif mencoba membelajarkan peserta didik untuk mau dan mampu menulis karya sastra. Proses kreatif para sastrawan dalam menciptakan karya sastra dapat digunakan sebagai acuan dalam mengembangkan metode pembelajaran sastra yang kreatif dan inovatif.

Salah satu metode yang digunakan dalam rangka pembelajaran menulis sastra, khususnya cerpen, adalah metode karyawisata. Tujuannya adalah agar peserta didik dapat mengamati secara langsung dan menghayati fenomena yang ada di sekelilingnya, sehingga merangsang pemunculan ide dan kreativitas dalam belajar menulis cerpen.

Metode karyawisata yang dilaksanakan secara bersama-sama dalam suasana menyenangkan menjadikan siswa dapat mengembangkan karakter dalam pergaulan sekaligus memperoleh rasa puas dalam belajar.
\end{abstract}

Kata kunci: pembelajaran, sastra, kreatif, inovatif, karyawisata

\section{PENDAHULUAN}

Pembelajaran sastra di sekolah seyogyanya dalam berbagai aspeknya diarahkan pada penumbuhan apresiasi sastra para siswa sesuai dengan tingkat kematangan emosionalnya. Hal ini mengisyaratkan bahwa perencanaan, pelaksanaan, dan evaluasi pembelajaran sastra idealnya diarahkan pada penumbuhan apresiasi pada siswa. Pembelajaran sastra pada lembaga pendidikan formal idealnya tidak hanya sebatas pada pemberian teks sastra dalam genre tertentu untuk dipahami dan diinterpretasikan oleh siswa (apresiasi reseptif), tetapi harus diarahkan pada penumbuhan kemampuan siswa dalam menilai atau mengkritik kelebihan dan kekurangan teks yang ada sehingga, berdasarkan penilaian/kritik tersebut, siswa mampu membuat sebuah teks lain yang lebih bermutu, baik teks yang masih dalam satu genre ataupun tidak (apresiasi produktif).

Siswanto (2008) mengungkapkan bahwa pendidikan kreatif sastra mencoba membelajarkan peserta didik untuk mau dan mampu menulis karya sastra. Memang, ada yang berpendapat bahwa menjadi sastrawan itu bersifat individual, namun dalam berbagai pengamatan dan percobaan, dengan metode tertentu dan model tertentu, orang-orang yang belum pernah stau belum bisa menulis karya sastra, ternyata mereka bisa menulis karya sastra setelah melalui pelatihan singkat. Bukti ini perlu dikembangkan menjadi sebuah mata pelajaran atau jurusan tersendiri di perguruan tinggi untuk secara khusus mengembangkan kemampuan dan kemauan menulis karya sastra.

Selama ini, dari berbagai observasi yang dilakukan oleh beberapa ahli terhadap pelaksanaan pembelajaran sastra di sekolah, aspek penulisan kreatif sastra ini kurang mendapat perhatian yang serius. Tidak banyak guru yang mempunyai metode atau model untuk 
melatih peserta didiknya untuk berproses kreatif. Tidak heran bila tidak banyak sastrawan muda yang lahir dari proses pembelajaran di lembaga pendidikan.

Dalam pandangan kritikus sastra, kian merananya pembelajaran sastra di sekolah lebih banyak disebabkan oleh dua faktor yang bermuara pada guru. Pertama, guru sebagai sosok pengajar dianggap kurang memiliki kompetensi dan basis pengetahuan sastra yang mumpuni. Kedua, guru dinilai tidak kreatif dalam proses pembelajaran (pengajaran) sastra di sekolah sehingga cenderung membosankan. Hal ini terjadi karena guru dinilai tidak memiliki strategi jitu. Dalam proses pembelajaran seorang guru dituntut untuk aktif, kreatif, inovatif, dan menciptakan strategi jitu. Guru juga dituntut mengembangkan kompetensinya sehingga mampu menciptakan pembelajaran yang berkualitas dari segi isi (materi) maupun kemasannya.

\section{METODOLOGI}

Analisis masalah dalam tulisan ini menggunakan metode deskriptif, yaitu berusaha menggambarkan atau menjelaskan peristiwa dan kejadian yang ada pada masa sekarang (Sudjana, 1999:52).

\section{PEMBAHASAN}

\section{Pembelajaran Sastra yang Kreatif dan Inovatif}

Apabila dilihat dari prosesnya, karya sastra merupakan hasil proses kreatif yang memerlukan perenungan, pengendapan ide, pematangan, langkah-langkah tertentu yang berbeda antara sastrawan satu dengan yang lain. Karya sastra bukanlah pekerjaan yang memerlukan keterampilan semata. Karya sastra memerlukan bakat, intelektualitas, wawasan kesastraan, sikap terbuka, jujur dan syarat lainnya.

Kegiatan yang dilakukan oleh sastrawan sebelum menulis pada umumnya adalah: (i) berjalan-jalan, bepergian ke kota atau tempat yang menarik, (ii) membaca, membaca apa saja terutama karya sastra atau hal-hal yang berkaitan dengan karya sastra, (iii) mendengarkan, mendengar dongeng, hikayat, cerita, atau tontonan wayang, dan lain-lain, dan (iv) memperoleh pengalaman. Kalau kita mau mencermati, sebelum menjadi sastrawan, para sastrawan yang sekarang sudah mapan ternyata juga melalui proses berlatih terlebih dahulu. Hanya saja, pelatihan yang mereka lakukan pada umumnya belum terstruktur dan belum ada kurikulumnya.

Kreatif berarti menggunakan hasil ciptaan/kreasi baru atau yang berbeda dengan sebelumnya. Pembelajaran yang kreatif mengandung makna tidak sekedar melaksanakan dan menerapkan kurikulum. Kurikulum memang merupakan dokumen atau rencana baku, namun tetap perlu dikritisi dan dikembangkan secara kreatif. Dengan demikian, ada kreativitas pengembangan kompetensi dan kreativitas dalam pelaksanaan pembelajaran di kelas termasuk pemanfaatan lingkungan sebagai sumber bahan dan sarana untuk belajar. Pembelajaran kreatif juga dimaksudkan agar guru menciptakan kegiatan belajar yang beragam sehingga memenuhi berbagai tingkat kemampuan siswa dan tipe serta gaya belajar siswa. Di satu sisi, guru bertindak kreatif dalam arti: (i) mengembangkan kegiatan pembelajaran yang 
beragam, dan (ii) membuat alat bantu belajar yang berguna meskipun sederhana. Di sisi lain, siswa kreatif dalam hal: (i) merancang/membuat sesuatu, dan (ii) menulis/mengarang.

Mc. Leod dalam Jauhar (2011) mengartikan inovasi sebagai: "something newly introduced such as method or device". Berkaitan dengan hal tersebut, segala aspek (metode, bahan, perangkat dan sebagainya) dipandang baru atau bersifat inovatif apabila metode dan sebagainya itu berbeda atau belum dilaksanakan oleh seorang guru meskipun semua itu bukan barang baru bagi guru lain. Pembelajaran inovatif dapat menyeimbangkan fungsi otak kiri dan otak kanan apabila dilakukan dengan cara mengintegrasikan media/alat bantu terutama yang berbasis teknologi baru/maju ke dalam proses pembelajaran tersebut. Sehingga, terjadi proses renovasi mental, di antaranya membangun rasa percaya diri siswa.

Membangun sebuah pembelajaran inovatif bisa dilakukan dengan cara-cara yang diantaranya menampung setiap karakteristik siswa dan mengukur kemampuan/daya serap setiap siswa. Sebagian siswa ada yang berkemampuan dalam menyerap ilmu dan keterampilan dengan menggunakan daya visual (penglihatan) dan auditory (pendengaran), sedang sebagian lainnya menyerap secara kinestetik (rangsangan/ gerakan otot dan raga). Di satu sisi, guru bertindak inovatif dalam hal: (i) menggunakan bahan/materi baru yang bermanfaat dan bermartabat, (ii) menerapkan pelbagai pendekatan pembelajaran dengan gaya baru, dan (iii) memodifikasi pendekatan pembelajaran konvensional menjadi pendekatan inovatif yang sesuai dengan keadaan siswa, sekolah dan lingkungan. Di sisi lain, siswa pun bertindak inovatif dalam arti: (i) mengikuti pembelajaran inovatif dengan aturan yang berlaku, (ii) berupaya mencari bahan/materi sendiri dari sumber-sumber yang relevan, dan (iii) menggunakan perangkat teknologi maju dalam proses belajar.

Terkait dengan pembelajaran yang kreatif dan inovatif, Peraturan Menteri Pendidikan Nasional Nomor 41 Tahun 2007 tentang Standar Proses mengamanatkan bahwa dalam kegiatan inti pembelajaran harus dilakukan secara interaktif, inspiratif, menyenangkan, menantang, memotivasi peserta didik untuk berpartisipasi aktif, serta memberikan ruang yang cukup bagi prakarsa, kreativitas, dan kemandirian sesuai bakat, minat, dan perkembangan fisik dan psikologis peserta didik. Metode pembelajaran sastra di sekolah perlu dikembangkan dengan mengacu pada prinsip-prinsip Pembelajaran Aktif, Inovatif, Kreatif, Efektif dan Menyenangkan (PAIKEM). Salah satu metode yang dapat dikembangkan dalam rangka meningkatkan keterampilan menulis sastra, khususnya cerpen dan puisi, adalah Metode Karyawisata. Metode ini dilaksanakan di luar kelas secara bersama-sama (berkelompok) dengan situasi yang menyenangkan.

\section{Metode Karyawisata}

Secara etimologi, karyawisata berasal dari kata "karya" yang berarti pekerjaan, hasil perbuatan, buatan, ciptaan (terutama hasil karangan) dan "wisata" yang berarti bepergian bersama-sama (untuk memperluas pengetahuan, bersenang-senang, dan sebagainya), bertamasya atau piknik. Dalam Kamus Besar Bahasa Indonesia, karyawisata diartikan sebagai 
kunjungan ke suatu objek dalam rangka memperluas pengetahuan dalam hubungannya dengan pekerjaan seseorang atau sekelompok orang.

Banyak istilah yang dipergunakan pada metode karyawisata ini, seperti field trip, widyawisata, studytour, dan sebagainya. Metode karyawisata dalam waktu pelaksanaanya ada yang dalam waktu singkat, dan ada pula yang dalam waktu beberapa hari atau waktu panjang. Contoh karyawisata dalam waktu singkat adalah kunjungan ke museum terdekat yang ada di kota setempat. Karyawisata dalam waktu yang lama dan tempat yang jauh biasanya disebut dengan istilah study tour, seperti karyawisata keluar provinsi, kabupaten, atau kota lain.

Karyawisata dalam arti metode pembelajaran di sini diartikan sebagai kunjungan ke luar kelas dalam rangka belajar. Dalam proses belajar mengajar adakalanya siswa perlu diajak ke luar sekolah, untuk meninjau tempat tertentu atau objek yang lain. Roestiyah (2001:85) dalam makalah "Metode Karyawisata: Pendekatan dalam Pembelajaran di Sekolah" mengemukakan bahwa karyawisata bukan sekedar rekreasi, tetapi untuk belajar atau memperdalam pelajarannya dengan melihat kenyataan. Karena itu dikatakan bahwa metode karyawisata ialah cara mengajar yang dilaksanakan dengan mengajak siswa ke suatu tempat atau objek tertentu di luar sekolah untuk mempelajari atau menyelidiki sesuatu.

Tujuan metode karyawisata antara lain:

a. Siswa dapat memperoleh pengalaman langsung dari objek yang dilihatnya.

b. Dapat turut menghayati tugas pekerjaan milik seseorang serta dapat bertanya jawab, sehingga mereka mampu memecahkan persoalan yang dihadapinya dalam pelajaran, ataupun pengetahuan umum.

c. Bisa melihat, mendengar, meneliti dan mencoba apa yang dihadapinya, agar nantinya dapat mengambil kesimpulan dan sekaligus dalam waktu yang sama ia bisa mempelajari beberapa mata pelajaran.

Mulyasa (2005) dalam makalah "Metode Karyawisata: Pendekatan dalam Pembelajaran di Sekolah" mengemukakan bahwa sebelum karyawisata digunakan dan dikembangkan sebagai metode pembelajaran, ada beberapa hal yang perlu diperhatikan, antara lain:

a. Menentukan sumber-sumber masyarakat sebagai sumber belajar mengajar.

b. Mengamati kesesuaian sumber belajar dengan tujuan dan program sekolah.

c. Menganalisis sumber belajar berdasarkan nilai-nilai paedagogis.

d. Menghubungkan sumber belajar dengan kurikulum, apakah sumber-sumber belajar dalam karyawisata menunjang dan sesuai dengan tuntutan kurikulum, jika ya, karyawisata dapat dilaksanakan.

e. Membuat dan mengembangkan program karyawisata secara logis dan sistematis.

f. Melaksanakan karyawisata sesuai dengan tujuan yang telah ditetapkan, dengan memperhatikan tujuan pembelajaran, materi pelajaran, efek pembelajaran, serta iklim yang kondusif.

g. Menganalisis apakah tujuan karyawisata telah tercapai atau tidak, apakah terdapat kesulitankesulitan perjalanan atau kunjungan, memberikan surat ucapan terima kasih kepada merekayang telah membantu, membuat laporan karyawisata dan catatan untuk bahan 
karyawisata yang akan datang.

Sebagaimana metode pembelajaran lainnya, metode karyawaisata memiliki kelebihan dan kekurangan. Kelebihan metode ini antara lain:

a. Membentuk pengalaman sensorik dengan merasakan langsung sebuah peristiwa.

b. Memperdalam pengamatan-pengamatan terhadap gejala alam dan menimbulkan minat dan perhatian terhadap benda-benda.

c. Memperkaya khasanah pengetahuan dan mengembangkan karakter pergaulan dengan lingkungan.

d. Merangsang kreativitas dan memberikan rasa puas.

e. Siswa dapat bertanya jawab, menemukan sumber informasi yang pertama untuk memecahkan segala persoalan yang dihadapi, sehingga mungkin mereka menemukan bukti kebenaran teorinya, atau mencobakan teorinya ke dalam praktek.

f. Siswa dapat memperoleh bermacam-macam pengetahuan dan pengalaman yang terintegrasi, yang tidak terpisah-pisah dan terpadu.

g. Membuat bahan yang dipelajari di sekolah menjadi lebih relevan dengan kenyataan dan kebutuhan yang ada di masyarakat.

Kekurangan metode karyawisata antara lain:

a. Memerlukan persiapan yang melibatkan banyak pihak dan perencanaan yang matang.

b. Waktu yang lebih panjang daripada jam sekolah.

c. Dalam karyawisata sering unsur rekreasi menjadi prioritas daripada tujuan utama, sedangkan unsur studinya terabaikan.

d. Memerlukan pengawasan yang lebih ketat terhadap setiap gerak-gerik anak didik di lapangan.

e. Memerlukan tanggung jawab guru dan sekolah atas kelancaran karyawisata dan keselamatan anak didik, terutama karyawisata jangka panjang dan jauh.

f. Karya wisata biasanya dilakukan di luar sekolah, sehingga mungkin jarak tempat itu sangat jauh dari sekolah yang memerlukan biaya besar.

Agar penggunaan metode karyawisata dapat efektif, maka pelaksanaannya perlu memperhatikan langkah-langkah sebagai berikut:

a. Persiapan.

Dalam merencanakan tujuan karyawisata, guru perlu menetapkan tujuan pembelajaran dengan jelas, penyusunan rencana yang masak, membagi tugas-tugas, mempersiapkan sarana, pembagian siswa dalam kelompok, serta mengirim utusan untuk mengadakan survei ke objek yang dituju.

b. Perencanaan.

Hasil kunjungan pendahuluan (survei) dibicarakan bersama dalam rangka menyusun perencanaan yang meliputi: tujuan karyawisata, jenis objek sesuai dengan tujuan, penyusunan acara selama karyawisata berlangsung dan merencanakan perlengkapan belajar yang harus disediakan.

c. Pelaksanaan karyawisata.

Pemimpin rombongan mengatur segalanya dibantu petugas-petugas lainnya. Kepada para siswa harus ditanamkan disiplin dalam mentaati jadwal yang telah direncanakan sehingga pelaksanaan berjalan lancar sesuai dengan rencana. Siswa melaksanakan tugas sesuai dengan pembagian yang telah 
ditetapkan dalam rencana kunjungan, sedangkan guru mengawasi, membimbing, bila perlu menegur sekiranya ada siswa yang kurang mentaati tata tertib.

d. Pembuatan laporan.

Siswa mengadakan diskusi mengenai segala hal hasil karyawisata, menyusun laporan atau paper yang memuat kesimpulan yang diperoleh. Hasil kegiatan karyawisata ditulis dalam bentuk laporan yang formatnya telah disepakati bersama.

\section{Menulis Cerpen}

Cerpen adalah salah satu jenis prosa fiksi, cerita naratif yang ditulis secara singkat (Thahar, 2002: 10). Fiksi berarti kisah yang tidak nyata, tidak benar-benar terjadi. Fiksi adalah fakta yang terhimpun dalam pengalaman batin seorang pengarang, lalu dikreasikan kembali dengan imajinasinya, sehingga menjadi sesuatu yang hidup dan menjadi suatu kenyataan baru. Arswendo menyebut 'kenyataan baru' itu sebagai realitas imajinatif, kenyataan yang dihasilkan dari imajinasi (Atmowiloto, 2010: 12)

Unsur-unsur cerpen meliputi:

a. Tema.

Tema adalah dasar cerita, suatu konsep, ide, atau gagasan yang menjadi dasar diciptakannya sebuah cerpen. Dengan kata lain, tema adalah roh atau jiwa cerita. (Rampan, 2003: 94)

b. Tokoh dan Penokohan.

Tokoh dalam cerpen adalah pelaku cerita. Tokoh dan penokohan merupakan cara seorang penulis cerita untuk mendeskripsikan tokoh yang diciptakannya.

c. Alur/Plot.
Alur/plot adalah jalan cerita, bagaimana sebuah cerita dirangkai dari awal hingga akhir. Berdasarkan bagaimana sebuah cerita diakhiri (ending cerita), plot dibedakan menjadi plot terbuka, plot tertutup, plot lembut, dan plot ledakan (Atmowiloto, 2010: 30-32). Berdasarkan waktu pengisahan, alur atau plot dibedakan menjadi alur maju, alur mundur (flash back), dan alur campuran. Dalam alur terdapat rangkaian peristiwa atau lazim disebut tahapan alur yang terdiri dari eksposisi (pengenalan), konflik, perumitan, klimaks, antiklimaks, dan penyelesaian.

d. Latar/Setting.

Latar adalah latar belakang cerita. Secara umum setting dibedakan menjadi setting tempat (dimana sebuah cerita terjadi), setting waktu (kapan sebuah cerita terjadi), dan setting suasana (bagaimana suasana sebuah cerita).

e. Sudut Pandang (Point of View/PoV).

Sudut pandang adalah bagaimana penulis menceritakan kisah yang ditulisnya, apakah menggunakan sudut pandang orang pertama (aku, saya), menggunakan sudut pandang orang kedua (kamu, kau), atau menggunakan sudut pandang orang ketiga (penulis berada diluar cerita dan biasanya bertindak 'serba tahu').

f. Gaya Bahasa.

Gaya bahasa adalah kemampuan pengarang menggunakan suatu bahasa untuk mengungkapkan ceritanya. Di samping sebagai tanda seorang pengarang, gaya tertentu mampu menyedot perhatian pembaca untuk terus membaca.

g. Pesan/Amanat. 
Pesan dalam cerpen adalah nilai-nilai kehidupan yang disampaikan penulis, seperti nilai moral, nilai agama, dan sebagainya. Ada beberapa catatan yang harus diperhatikan dalam menyisipkan pesan moral.

Secara umum, langkah-langkah menulis cerpen adalah sebagai berikut.

a. Menentukan Tema.

Ide untuk pengembangan tema cerpen yang akan ditulis bisa digali dari fakta/realita seharihari (seperti pengalaman pribadi, cerita teman, dan buku harian), imajinasi (seperti khayalan dan mimpi), atau perpaduan antara fakta dan imajinasi (seperti buku fiksi dan film).

b. Menentukan tokoh dan penokohannya.

Dalam proses ini, penulis menentukan siapa tokoh protagonis dan antagonisnya, lalu mendeskripsikan seperti apa ciri fisik dan watak khasnya.

c. Menyusun kerangka karangan (outline).

Menyusun outline bisa dimulai dengan membuat peta pikiran (mind mapping), lalu mengembangkannya menjadi kerangka utuh.

Outline sangat berguna untuk mengingatkan apa yang ingin ditulis dan memudahkan penulis untuk mengedit hasil tulisan.

d. Menulis ringkasan cerita/sinopsis/garis besar cerita.

Garis besar cerita berisi poin-poin peristiwa penting yang akan terjadi dalam cerita.

e. Menjabarkan sinopsis menjadi cerita yang lengkap.

Proses ini adalah proses utama yang akan menentukan keberhasilan sebuah cerpen. Ada dua pertanyaan penting yang akan membantu penulis cerpen untuk mengembangkan sinopsis yang telah dibuat. Pertanyaan ini berkaitan dengan tokoh cerita. Pertanyaan tersebut yaitu siapa mereka dan apa yang terjadi pada mereka? Jawaban pertanyaan ini akan membantu proses pengembangan cerita (Bird, 2001: 91).

f. Menentukan judul.

Judul cerpen biasanya ditulis secara singkat (tidak lebih dari lima kata). Judul yang baik adalah yang bisa menarik perhatian pembaca, unik, membuat pembaca penasaran (terkesan bombastis).

\section{Metode Karya Wisata pada Pembelajaran Menulis Cerpen}

Modal dasar untuk menulis fiksi, termasuk cerpen, adalah kepekaan, kreativitas, dan daya imajinasi (Bird, 2001: 39). Kepekaan melihat fenomena atau realitas akan memunculkan ide yang tak terduga. Dengan menghayati pengalaman, seseorang akan lebih mudah menuangkap ide untuk menulis. Metode karyawisata diharapkan akan memberikan rangsangan kepada peserta didik untuk menggali ide dan berproses kreatif dalam menulis cerpen dan puisi melalui ketertarikannya pada alam sekitar.

Pelaksanaan metode karyawisata dalam kaitannya dengan pembelajaran menulis cerpen mengikuti langkah-langkah sebagai berikut:

a. Siswa diajak ke lokasi yang menarik, misalnya taman kota.

b. Siswa dibagi dalam kelompok kecil dengan jumlah anggota kurang lebih 5 orang.

c. Guru menjelaskan pengertian cerpen, unsurunsur cerpen dan langkah-langkah menulis cerpen.

d. Masing-masing kelompok diberi tugas untuk mengamati fenomena alam atau peristiwa 
tertentu pada suatu tempat.

e. Masing-masing siswa dalam kelompok diberi tugas untuk mengamati salah satu objek yang menarik minat dan menjadi fokus perhatian, boleh manusia, hewan, tumbuhan atau benda.

f. Siswa diberi tugas untuk menulis cerpen sesuai dengan fokus perhatian mereka dengan catatan sebagai berikut:

1) Tokoh cerpen yang ditulis adalah salah sat objek yang menjadi fokus perhatian.

2) Sudut pandang bebas (orang pertama, kedua atau ketiga).

3) Setting adalah situasi lingkungan sekitar objek yang dipilih.

4) Alur/plot bebas.

5) Mengacu pada langkah-langkah menulis cerpen.

g. Siswa mendiskusikan hasil penulisan cerpennya di dalam kelompok masing-masing, kemudian memperbaiki penulisannya.

h. Masing-masing kelompok mempresentasikan hasil cerpen yang dianggap terbaik.

i. Siswa mengaprsiasi cerpen dengan metode diskusi kelompok yang dipandu oleh guru untuk merumuskan hal-hal yang diperlukan untuk memperbaiki hasil penulisan cerpen.

j. Siswa memperbaiki penulisan cerpen.

k. Siswa kembali ke sekolah dan membuat laporan hasil karyawisata.

\section{KESIMPULAN}

Pengembangan pembelajaran sastra dapat dilakukan dengan cara belajar dari proses kreatif yang telah dilalui para sastrawan dalam menciptakan karya sastra dan mengacu pada metode pembelajaran sastra yang kreatif dan inovatif. Salah satu metode yang dapat digunakan dalam rangka pembelajaran menulis sastra, khususnya cerpen, adalah metode karyawisata. Tujuannya adalah agar peserta didik dapat mengamati secara langsung dan menghayati fenomena yang ada di sekelilingnya, sehingga merangsang pemunculan ide dan kreativitas dalam belajar menulis cerpen. Metode karyawisata dilaksanakan secara bersama-sama dalam suasana menyenangkan, sehingga siswa dapat mengembangkan karakter dalam pergaulan sekaligus memperoleh rasa puas dalam belajar.

\section{DAFTAR PUSTAKA}

Atmowiloto, Arswendo. 2010. Mengarang Itu Gampang. Jakarta: Gramedia.

Bird, Carmel. 2001. Menulis Dengan Emosi: Panduan Empatik Mengarang Fiksiterjemahan Eva Y. Nukman (dari The Classic Guide to Writing Fiction). Bandung: Kaifa.

Delsajoesafira. 2012. "Metode Karyawisata". http://delsajoesafira.blogspot.com/ diakses pada tanggal 16 Maret 2012.

Jauhar, Mohammad. 2011. Implementasi PAIKEM dari Behavioristik sampai Konstruktivistik: Sebuah Pengembangan Pembelajaran Berbasis CTL (Contextual Teaching \& Learning). Jakarta: Prestasi Pustakaraya.

Makalah "Metode Karyawisata: Pendekatan dalam Pembelajaran di Sekolah". 2012. http://www.scribd.com/ diakses tanggal 16 Maret 2012.

Nurgiyantoro, Burhan. 2001. Penilaian dalam Pembelajaran Bahasa dan Sastra. Yogyakarta: BPFE

Rampan, Korrie Layun. 2003. Teknik Menulis Cerita Anak. Yogyakarta: Pink Books.

Thahar, Harris Effendi. 2002. Kiat Menulis Cerita Pendek. Bandung: Angkasa.

Siswanto, Wahyudi. 2008. Pengantar Teori Sastra. Jakarta: PT Grasindo. 
Siswanto, Wahyudi. Tanpa Tahun. "Makalah Model Pembelajaran Menulis Puisi". Jakarta: PT Grasindo

Sudjana, Nana. 1999. Penelitian Pendidikan. Jakarta: Rineka Cipta.

Waluyo, Heman J. 1995. Teori dan Presiasi Puisi. Jakarta: Penerbit Erlangga. 